\title{
Finance and \\ Financial \\ Markets
}

Second Edition

Keith Pilbeam 


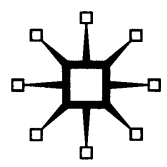

ISBN 978-0-333-62945-1 ISBN 978-1-349-26273-1 (eBook)

DOI 10.1007/978-1-349-26273-1

(C) Keith Pilbeam 1998, 2005

Reprint of the original edition 2005

All rights reserved. No reproduction, copy or transmission of this publication may be made without written permission.

No paragraph of this publication may be reproduced, copied or transmitted save with written permission or in accordance with the provisions of the Copyright, Designs and Patents Act 1988, or under the terms of any licence permitting limited copying issued by the Copyright Licensing Agency, 90 Tottenham Court Road, London W1T 4LP.

Any person who does any unauthorized act in relation to this publication may be liable to criminal prosecution and civil claims for damages.

The author has asserted his right to be identified as the author of this work in accordance with the Copyright, Designs and Patents Act 1988.

First edition 1998

Reprinted six times

Second edition 2005

Published by

PALGRAVE MACMILLAN

Houndmills, Basingstoke, Hampshire RG21 6XS and

175 Fifth Avenue, New York, N.Y. 10010

Companies and representatives throughout the world

PALGRAVE MACMILLAN is the global academic imprint of the Palgrave Macmillan division of St. Martin's Press, LLC and of Palgrave Macmillan Ltd. Macmillan ${ }^{\circledR}$ is a registered trademark in the United States, United Kingdom and other countries. Palgrave is a registered trademark in the European Union and other countries.

ISBN 978-1-4039-4835-9 paperback

This book is printed on paper suitable for recycling and made from fully managed and sustained forest sources. Logging, pulping and manufacturing processes are expected to conform to the environmental regulations of the country of origin.

A catalogue record for this book is available from the British Library.

Library of Congress Cataloging-in-Publication Data

Pilbeam, Keith

Finance and financial markets / Keith Pilbeam-2nd ed.

p. $\mathrm{cm}$.

Includes bibliographical references and index.

ISBN 978-1-4039-4835-9 (paper)

1. Finance. 2. Financial institutions. I. Title.

HG173.P535 2005

332-dc22

2005042142

$\begin{array}{rrrrrrr}10 & 9 & 8 & 7 & & & \\ 14 & 13 & 12 & 11 & 10 & 09 & 08\end{array}$


To Fiona, Penny and Eamon 


\section{Brief contents}

1 The world of finance 1

2 Financial intermediation and financial markets $\quad 22$

3 Financial institutions $\quad 39$

4 Monetary policy and interest rate determination 61

5 Domestic and international money markets 96

6 The domestic and international bond market $\quad 117$

7 Portfolio analysis: risk and return in financial markets 156

8 The capital asset pricing model 188

9 Stockmarkets and equities $\quad 215$

10 The efficiency of financial markets 247

11 The foreign exchange market 269

12 Theories of exchange rate determination 300

13 Financial futures 334

14 Options 362

15 Option pricing 388

16 Swap markets $\quad 412$

17 Regulation of the financial sector 432 


\section{Contents}

1 The World of Finance 1

1.1 Introduction 1

1.2 Financial centres 2

1.3 The role of a financial centre 3

1.4 Money markets, capital markets and the banking system 5

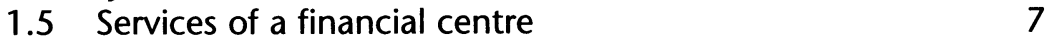

1.6 The growth of the financial services industry 10

$\begin{array}{ll}1.7 & \text { The globalization of financial markets } \\ 10\end{array}$

$\begin{array}{lll}1.8 & \text { Technology } & 11\end{array}$

$\begin{array}{ll}1.9 \text { Deregulation } & 13\end{array}$

1.10 Financial innovation $\quad 15$

1.11 Types of financial innovations $\quad 16$

$\begin{array}{ll}1.12 \text { Emerging markets } & 16\end{array}$

1.13 Problems concerning investment in emerging markets 17

$\begin{array}{ll}1.14 \text { The future } & 18\end{array}$

1.15 Conclusions $\quad 20$

2 Financial Intermediation and Financial Markets 22

2.1 Introduction 22

2.2 Surplus and deficit agents 23

2.3 What is a financial security? 24

2.4 Types of financial claims: debt and equity 24

2.5 The role of financial intermediaries 26

2.6 Provision of a payments mechanism 26

2.7 Maturity transformation 27

2.8 Risk transformation 27 
2.9 Liquidity provision 29

2.10 Reduction of contracting, search and information costs 29

2.11 Types of financial markets $\quad 30$

2.12 The classification of financial markets 33

2.13 The role played by financial markets 34

2.14 Participants in financial markets $\quad 34$

2.15 Conclusions $\quad 36$

3 Financial Institutions 39

$\begin{array}{lll}3.1 & \text { Introduction } & 39\end{array}$

$\begin{array}{ll}3.2 & \text { The central bank } \\ 3.3\end{array}$

3.3 The implementation of monetary policy 41

3.4 Management of the national debt 41

$\begin{array}{ll}3.5 & \text { Supervisory function } \\ 3.6 & 41\end{array}$

3.6 Types of financial intermediaries $\quad 43$

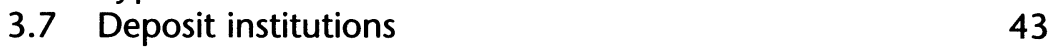

3.8 The banking sector $\quad 44$

3.9 Savings institutions $\quad 45$

3.10 Insurance companies 45

3.11 The phenomenon of Bancassurance 47

3.12 Mutual funds or unit trusts $\quad 48$

3.13 Investment companies and investment trusts 49

$\begin{array}{ll}3.14 \text { Pension funds } & 51\end{array}$

3.15 Specialist financial institutions $\quad 52$

3.16 Venture capital companies $\quad 52$

3.17 Hedge funds $\quad 53$

3.18 Finance companies or finance houses 55

3.19 Factoring agencies $\quad 56$

3.20 The role of financial institutions $\quad 57$

$\begin{array}{ll}3.21 \text { Conclusions } & 58\end{array}$

4 Monetary Policy and Interest Rate Determination 61

4.1 Introduction 61

4.2 The functions of money 62

4.3 Bills and bonds 62

4.4 The operation of monetary policy 64

4.5 Monetary policy in practice and the announcement $\begin{array}{ll}\text { effect } & 67\end{array}$

4.6 The commercial banking system and the narrow and broad money supply 70

$\begin{array}{ll}4.7 & \text { Formula for the money multiplier } \\ 4.83 & \text { Controling the money supply }\end{array}$

4.8 Controlling the money supply 74

4.9 The determination of interest rates 75

4.10 The loanable funds approach to interest rate
determination 
4.11 Money market or loanable funds theory? 80

4.12 Inflation and interest rates $\quad 81$

4.13 Fiscal policy and interest rates $\quad 84$

4.14 Other factors influencing the interest rate $\quad 84$

4.15 Theories of the yield curve 85

4.16 Expectations theory $\quad 87$

4.17 Liquidity preference theory $\quad 89$

$\begin{array}{lr}4.18 \text { Preferred habitat theory } & 89\end{array}$

4.19 Market segmentation theory 90

4.20 The importance of alternative views of the term
structure

4.21 Problems with monetary policy 92

4.22 Conclusions $\quad 92$

5 Domestic and International Money Markets 96

5.1 Introduction 96

5.2 Types of domestic money market instruments 97

$\begin{array}{lll}5.3 & \text { Treasury bills } & 97\end{array}$

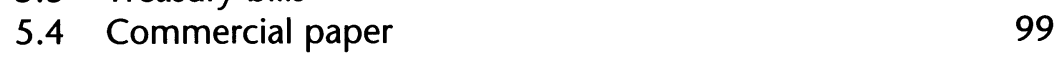

5.5 The interbank market 100

5.6 Bankers' acceptances 100

$\begin{array}{ll}5.7 & \text { Repurchase agreements } \\ 5.8 & 101\end{array}$

5.8 Certificates of deposit 102

5.9 The international money market 103

$\begin{array}{ll}5.10 \text { Euromarkets } & 103\end{array}$

5.11 The origins and development of the Euromarkets $\quad 104$

5.12 The characteristics of the Eurodollar market 106

5.13 The competitive advantage of Eurobanks 107

5.14 The coexistence of domestic and Eurobanking 109

5.15 The creation of Eurodeposits 109

5.16 The pros and cons of the Eurocurrency markets 111

5.17 Syndicated loans $\quad 111$

$\begin{array}{ll}5.18 \text { Euronotes } & 112 \\ 5.19 \text { Conclusions } & 113\end{array}$

5.19 Conclusions 113

6 The Domestic and International Bond Market 117

$\begin{array}{ll}6.1 \text { Introduction } & 118\end{array}$

$\begin{array}{ll}\text { 6.2 Trading in government bonds } & 118\end{array}$

6.3 Determining the price of government bonds 118

6.4 Clean and dirty bond prices 121

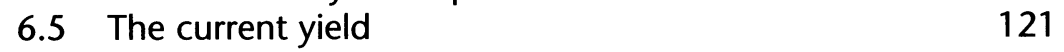

6.6 The simple yield to maturity 122

6.7 Yield to maturity 122

6.8 The par value relation 124

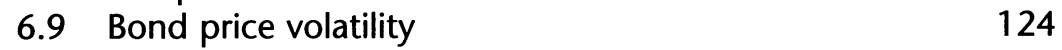


6.10 Duration

6.11 Modified duration 127

6.12 The duration for a portfolio of bonds 130

6.13 A formula to calculate duration

6.14 Duration and the problem of curvature of the bond-price relationship

6.15 The usefulness of the duration measure

6.16 Yield curves

6.17 Corporate bonds

6.18 Credit ratings

6.19 Risks associated with corporate bonds

6.20 Financial innovation and corporate bonds

6.21 Junk bonds

6.22 Medium-term notes

6.23 The international capital market

6.24 Motivations behind international capital flows

6.25 The origins and development of the Eurobond market

6.26 Typical features of a Eurobond

6.27 Control and regulation of the Eurobond market

6.28 The management of a Eurobond issue

6.29 Innovations in the Eurobond market

6.30 Conclusions

7 Portfolio Analysis: Risk and Return in Financial Markets

7.1 Introduction

7.2 Determining the price of a financial asset

7.3 The rate of return on a security

7.4 The variance and standard deviation of the rate of return

7.5 Risk on a security

7.6 Covariance and correlation of rates of return 162

7.7 Different types of investors

7.8 The indifference curves of risk-averse investors

7.9 Portfolio theory

7.10 Reducing risk through diversification

7.11 Measuring risk on a portfolio

7.12 The two-asset efficiency frontier

7.13 The minimum variance portfolio in the two risky asset case

7.14 The portfolio efficiency frontier

7.15 Market risk and specific risk

7.16 The efficient set with a riskless security

7.17 The market portfolio 
7.18 The market price of risk

7.19 Measuring the market index

8 The Capital Asset Pricing Model 188

$\begin{array}{ll}8.1 \text { Introduction } & 188\end{array}$

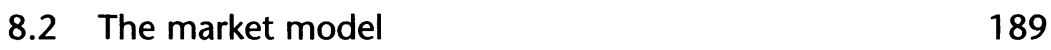

8.3 Portfolio risk and return using the market model 191

8.4 The capital asset pricing model 192

8.5 Assumptions of the CAPM 193

8.6 The theory behind the CAPM 194

8.7 Expressing the CAPM in risk premium form 198

8.8 The securities market line 199

8.9 The CAPM in action: measuring the beta coefficient 202

8.10 Empirical testing of the CAPM 204

8.11 The empirical evidence on the CAPM 205

8.12 The multifactor CAPM 207

8.13 The arbitrage pricing theory critique of the CAPM 208

8.14 Conclusions 209

9 Stockmarkets and Equities 215

9.1 Introduction 215

9.2 The major international stockmarkets 216

9.3 Stockmarket participants 218

9.4 The primary and secondary market 218

9.5 Different types of equity 219

9.6 The buying and selling of shares 220

$\begin{array}{ll}9.7 \text { A rights issue } & 221\end{array}$

9.8 A simple model of the pricing of a rights issue 222

9.9 Does the performance of the stockmarket matter? 223

9.10 The pricing of equities $\quad 224$

9.11 The dividend pricing approach 224

9.12 The Gordon growth model 225

9.13 A non-constant growth version of the dividend 228

9.14 The dividend irrelevance theorem 229

9.15 Measurement of the required rate of return 229

9.16 The subjectivity of share pricing 231

9.17 Forecasting future dividends: business risk and the
effects of gearing

9.18 Debt or equity finance? 236

9.19 Other approaches to equity valuation: financial ratio analysis 237

9.20 The usefulness of financial ratios 242

9.21 Conclusions 243 
10 The Efficiency of Financial Markets

10.1 Introduction

10.2 Three levels of efficiency

10.3 The efficient market hypothesis and a random walk

10.4 Implications of various forms of efficiency tests

10.5 Active versus passive fund management

10.6 Testing for weak market efficiency

10.7 Tests of the random-walk hypothesis

10.8 Filter rule tests

10.9 Other statistical tests

10.10 The day of the week effects

10.11 The January effect

10.12 The winner-loser problem 257

10.13 Testing for semi-strong market efficiency 258

10.14 The results of event studies

10.15 The size effect

10.16 The price-earnings effect

10.17 The earnings-announcement effect

10.18 Stockmarket crashes

10.19 Testing the strong form of market efficiency

10.20 Directors'/managers' share purchases

10.21 Information content of analysts forecasts

10.22 Conclusions

\section{The Foreign Exchange Market}

11.1 Introduction

11.2 Exchange rate definitions

11.3 Characteristics of and participants in the foreign exchange market

11.4 Arbitrage in the foreign exchange market

11.5 The spot and forward exchange rates

11.6 A simple model for determining the spot exchange rate

11.7 Alternative exchange rate regimes

11.8 Determination of the forward exchange rate 284

11.9 Nominal, real and effective exchange rates

11.10 Conclusions

12 Theories of Exchange Rate Determination

12.1 Introduction

12.2 Purchasing power parity theory 301

12.3 Absolute PPP 302

12.4 Relative PPP 303

12.5 Measurement problems in testing for PPP 303

12.6 Empirical evidence on PPP 305 
12.7 Summary of the empirical evidence on PPP

12.8 Explaining the poor performance of purchasing power parity

12.9 Modern theories of exchange rate determination

12.10 Uncovered interest rate parity

12.11 Monetary models of exchange rate determination

12.12 The flexible-price monetary model

12.13 The Dornbusch sticky-price monetarist model

12.14 A simple explanation of the Dornbusch model

12.15 A formal explanation of the Dornbusch model

12.16 A money supply expansion and exchange rate overshooting

12.17 Importance of the Dornbusch overshooting model

12.18 The Frankel real interest rate differential model

12.19 Conclusions

13.1 Introduction 334

13.2 The growth of futures exchanges 335

13.3 Comparison between futures and forward contracts 336

13.4 The symmetry of profits/losses on futures/forward positions

13.5 Exchange-traded derivative contracts versus the over-the-counter market

13.6 Trading in exchange futures contracts 340

13.7 The role of the clearing house

13.8 Open-interest and reversing trades

13.9 Stock-index futures

13.10 The pricing of a stock futures index 346

$\begin{array}{ll}13.11 \text { Short-term interest rate futures } & 348\end{array}$

13.12 The pricing of sterling futures $\quad 350$

13.13 Using interest rate futures 352

13.14 Bond futures contracts 353

13.15 Currency futures 355

13.16 The pricing of currency futures 357

13.17 Conclusions 358

\section{Options}

14.1 Introduction 362

14.2 The growth of options markets 363

14.3 Options contracts 363

14.4 A call option contract 365

14.5 A put option contract 367

14.6 Stock-index options 369

$\begin{array}{ll}14.7 & \text { Interest rate options } \\ \end{array}$ 
$\begin{array}{lll}14.8 & \text { Currency options } & 372\end{array}$

14.9 The uses of option contracts 373

14.10 Differences between options and futures contracts 375

14.11 A currency option versus a forward contract for hedging $\quad 376$

14.12 A currency option versus a forward for speculating 378

14.13 Option strategies $\quad 379$

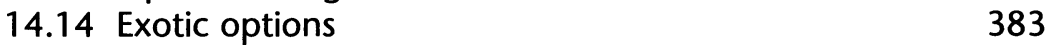

$\begin{array}{ll}14.15 \text { Conclusions } & 384\end{array}$

15 Option Pricing 388

15.1 Introduction 388

15.2 Principles of option pricing 389

15.3 Intrinsic value and time value 390

15.4 The distribution of the option premium between time and intrinsic value $\quad 391$

15.5 The Black-Scholes option pricing formula 396

$\begin{array}{lll}15.6 & \text { Different measures of volatility } & 401\end{array}$

15.7 The calculation of historical volatility 402

15.8 Problems with the Black-Scholes option pricing formula 403

15.9 The sensitivity of options prices 403

15.10 Put-call parity $\quad 404$

$\begin{array}{ll}15.11 \text { Conclusions } & 407\end{array}$

16 Swap Markets 412

16.1 Introduction $\quad 412$

16.2 Potential swap scenarios $\quad 414$

16.3 An interest rate swap 416

16.4 A currency swap agreement 420

16.5 The role of the intermediary in the swap 423

16.6 The secondary market in swaps 425

16.7 Distinguishing characteristics of the swap market
from the forward and futures markets

16.8 Reasons for the existence of the swap market 426

16.9 Innovations in the swap market 427

16.10 Conclusions $\quad 428$

17 Regulation of the Financial Sector 432

17.1 Introduction $\quad 432$

17.2 The rationale for government intervention 433

17.3 The objectives of government regulation 435

17.4 Types of government regulation 435

17.5 Regulation of the banking sector 438

$\begin{array}{lll}17.6 & \text { Statutory versus self-regulation } & 439\end{array}$ 
17.7 Regulation in the United Kingdom 440

17.8 Big Bang, $1986 \quad 441$

17.9 The Financial Services Act $1986 \quad 442$

17.10 The Banking Act $1987 \quad 444$

17.11 European regulation $\quad 444$

17.12 The First Banking Directive $1977 \quad 445$

17.13 The Second Banking Directive 1989

17.14 International regulation: the Basle Accord $1988 \quad 447$

17.15 The Basle II Accord $2004 \quad 450$

17.16 Conclusions $\quad 454$

Solutions to Multiple Choice Questions 455

$\begin{array}{ll}\text { Glossary } & 457\end{array}$

$\begin{array}{ll}\text { References } & 468\end{array}$

$\begin{array}{lr}\text { Further Reading } & 472\end{array}$

$\begin{array}{ll}\text { Index } & 475\end{array}$ 


\section{List of Tables}

1.1 GDP data (2003) and global stockmarkets (end 2004)

(US $\$$ billions)

1.2 Global debt securities, 2002 (US \$ billions) 6

1.3 Bank assets, 2002 (US \$ billions) 7

1.4 The importance of different financial centres, 2001-04 8

1.5 The world's largest insurance markets, 2002

1.6 Distribution of funds under management, 2001 (US $\$$ billions)

1.7 Derivative exchanges, 2003, by daily notional value of turnover (US $\$$ billions)

2.1 Types of financial liabilities

4.1 The relationship between base money, bank deposits and broad money

5.1 The gross size of the Eurocurrency market, selected years 104

5.2 The global market in syndicated loans, full year $2003 \quad 112$

6.1 Bond prices for different yields to maturity 125

6.2 Modified duration of a $£ 7$ coupon bond with par value of $£ 100$ and initial yield of $8 \%$

6.3 Modified duration bonds of differing coupon payments and different yields

6.4 The yield curve, coupon payments and bond prices 133

6.5 Credit-rating systems on corporate debt 135

6.6 Moodys corporate bond yield averages (long-term bonds), annual averages 1980-2004

6.7 Bond ratings and average yield spreads versus treasuries

6.8 Average global cumulative issuer-weighted default rates for differently rated bonds, 1970-2003

6.9 International bond issues by currency, 2004 
6.10 Features of a typical dollar Eurobond issue

6.11 Top international bond lead managers, 2004

7.1 The mean-standard-deviation frontier

7.2 The number of shares in a portfolio and correlation with the market

9.1 The main stockmarkets of the world, 2004 (\$ billions) 217

9.2 The effect of primary gearing on net earnings

9.3 The effect of primary gearing on equity return

9.4 The effect interest rates and primary gearing on profits

9.5 Analysing a company's financial performance

11.1 Foreign exchange market turnover

11.2 Exchange rate quotations at close of business 11 August 2004 (closing mid-points)

11.3 Foreign exchange cross rates at close of business 11 August 2004

11.4 Derivation of the demand for pounds

11.5 The supply of pounds

11.6 The $\$ / £$ forward exchange quotations and UK and US interest rates, 11 August 2004

11.7 Construction of nominal and real exchange rate indices

11.8 Construction of an effective exchange rate index

11.9 Nominal effective exchange rate indices, 1980-2004

295

11.10 Real effective exchange rate indices, 1980-2004

13.1 Turnover of futures contracts traded on international exchanges

13.2 Similarities and differences between currency forwards and futures

13.3 FTSE 100 index futures

13.4 Three-month sterling futures (LIFFE), $£ 1$ million

13.5 Contract specifications of LIFFE government bond futures contracts

13.6 Dollar-euro currency futures (CME) 355

14.1 Turnover of options traded on international exchanges 363

14.2 LIFFE equity options 364

14.3 Profit and loss profiles on a call option 366

14.4 Profit and loss profiles on a put option 368

14.5 Call and put contracts on the FTSE 100 index 370

14.6 Profit and loss profile on a FTSE 100 call index option 371

14.7 Short sterling options (Euronext LIFFE) 371

14.8 CME \$/€ options, €125,000 373

14.9 Comparison of hedging using futures and options 377

14.10 A currency option versus a currency forward for speculation 378 
14.11 The profit/loss profile from a long straddle

14.12 The profit/loss profile from a long strangle

15.1 Summary of factors affecting an option's price 390

15.2 In-the-money, at-the-money and out-of-the-money options 391

15.3 Intrinsic value and time value

15.4 The values of $N(d 1)$ and $N(d 2)$ for different current share prices

15.5 Example calculation of volatility

15.6 Creation of a riskless hedge portfolio

15.7 Creating a risk-free portfolio

15.8 The cumulative distribution function for the standard normal random variable

16.1 Currency composition of notional principal value of outstanding interest rate and currency swaps

16.2 Managing interest rate risk

16.3 An absolute advantage swap

16.4 A comparative advantage swap

16.5 A currency swap

17.1 Risk weighting under the 1988 Basle Accord 


\section{List of Figures}

1.1 The role of a financial centre 3

4.1 The effects of an expansionary OMO 65

4.2 The effects of a contractionary OMO 66

4.3 Summary of expansionary and contractionary monetary policies

4.4 The effects of an unexpected cut in the short-term interest rate

4.5 The effects of an unexpected rise in the short-term interest rate

4.6 The supply and demand for money 77

4.7 The effects of increases in money demand and money supply

4.8 The supply and demand for loanable funds

4.9 The effects of increases in demand and supply of loanable funds

4.10 Various yield curves

5.1 Comparison of US certificate of deposit and Eurodollar interest spreads

5.2 The creation of Eurobanking activity

6.1 The convex relationship between bond prices and yield 125

6.2 Duration and the problem of curvature 132

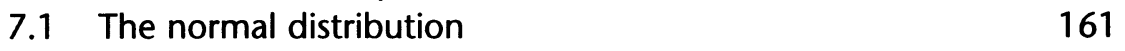

7.2 Indifference curves in risk-return space 165

7.3 The mean-standard-deviation frontier for a zero correlation coefficient

7.4 The mean-standard-deviation frontier for different values of the correlation coefficient 
7.5 The portfolio efficiency frontier

7.6 The effect on risk of increasing the number of shares in a portfolio

7.7 The portfolio opportunity set with a risk-free asset and a risky asset

7.8 The capital market line with $N$ securities

8.1 The market model

8.2 The capital market line and the market portfolio

8.3 The securities market line

8.4 The theoretical and empirical securities market lines

9.1 The pricing of a rights issue

10.1 Filter-rule tests

10.2 The impact of news according to the EMH

11.1 The organization of the foreign exchange market

11.2 The demand for pounds

11.3 The supply of pounds

11.4 Determination of the dollar-pound exchange rate

11.5 Floating exchange rate regime: supply and demand

11.6 Fixed exchange rate regime: demand shock

11.7 Fixed exchange rate regime: supply shock

11.8 Joint determination of the spot and forward exchange rate

11.9 Evolution of the dollar-pound nominal and real exchange rate, 1980-2004

11.10 Evolution of the yen-dollar nominal and real exchange rate, 1980-2004

11.11 Evolution of the euro-dollar nominal and real exchange rate, 1999-2004

12.1 The actual exchange rate and the PPP dollar-pound rate

12.2 The actual exchange rate and the PPP deutschmark-dollar rate

12.3 The actual exchange rate and the PPP yen-dollar rate

12.4 The actual exchange rate and the PPP deutschmarkpound rate

12.5 The actual exchange rate and the PPP french francdeutschmark rate

12.6 The actual exchange rate and the PPP lira-deutschmark rate

12.7 The dynamics of the Dornbusch overshooting model

12.8 The goods market equilibrium schedule

12.9 The money market equilibrium schedule

12.10 Equilibrium in the Dornbusch model 
12.11 Exchange rate overshooting

13.1 Profits/losses on a forward/futures contract 329

13.2 Typical open-interest profile 342

14.1 The profit and loss profile of a call option 367

15.1 A log-normal distribution 392

15.2 Intrinsic value and time value 393

15.3 The distribution of a call premium between intrinsic and time value

395

16.1 A comparative advantage swap 419

16.2 A currency swap $\quad 422$

16.3 The role of an intermediary in a swap 424 


\section{Preface}

The importance of financial markets, institutions and instruments to the successful operation of a modern economy has grown markedly during the last four decades. Indeed, the world of finance has itself undergone remarkable changes during this period. Financial institutions have become less regulated and increasingly international in their outlook. Markets are less segmented, with changes in money markets, foreign exchange, bond markets, stockmarkets and derivative markets becoming ever more inextricably linked. Moreover, domestic and foreign markets are increasingly interdependent with movements in foreign financial markets exerting significant impacts on domestic markets. More recently, the range of international financial markets has increased with developing countries such as China and India experiencing very high rates of economic growth and attempting to improve the functioning of their financial institutions and markets, with, likewise, the Eastern-bloc countries keen to develop their financial services sectors. Finally, the range of financial instruments traded has mushroomed, with investors and borrowers being able to choose from an ever-increasing range of risk-return products. A good example of this latter phenomenon has been the exponential growth of trading in derivative instruments such as options, futures and swaps.

The increasing importance of finance has inevitably been reflected in the popularity of courses dealing with finance theory, financial markets and financial instruments at both the undergraduate and postgraduate level. Indeed, these days virtually all MBA programmes have finance-related core or elective courses. This second edition of Finance and Financial Markets is designed to be a comprehensive and at the same time accessible introduction to financial institutions, markets and instruments aimed at undergraduate and MBA students. Many excellent books on finance are written to quite an advanced level and tend to adopt a relatively technical approach to the topic. The aim of this book is to provide a less technical and more practically 
oriented introduction to the field of finance whilst maintaining a reasonable degree of rigour. The book provides enough coverage to satisfy most introductory courses; however, it is hoped that the book will also serve as a springboard to the more advanced texts.

The opening five chapters provide an introduction to the world of finance and cover the basic theory relating to the operation of financial institutions and the domestic and offshore (Eurocurrency) money markets. Chapters 6 to 10 deal with both the theory and practice relating to capital markets. The theory covers areas such as portfolio diversification, the capital asset pricing model, the Gordon growth model and the efficient market hypothesis, while the practice looks at the domestic and international bond markets and equity markets.

Chapters 11 and 12 are devoted to the foreign exchange market, with Chapter 11 providing an introduction to the spot and forward markets and Chapter 12 providing an analysis of purchasing power parity theory and more modern theories of exchange rate determination. Chapters 13 to 16 are concerned with derivative instruments. Chapter 13 looks at forwards and futures contracts, and specific examples of currency, bond and equity index contracts are included. Chapters 14 and 15 look at options; Chapter 14 looks at what options are and how they can be used for speculative and hedging purposes, and at various option strategies, whilst Chapter 15 focuses on the more complex issue of option pricing and in particular the Black-Scholes option pricing formula. Chapter 16 looks at the swap market, which since the first swaps agreements were made in the 1980s has become increasingly important to the operation of domestic and international bond markets. Finally, Chapter 17 provides an analysis of the crucial issue of regulation of the financial sector.

This second edition has undergone quite substantial change including a substantial amount of new data being added and extensive rewriting along with the incorporation of more worked examples. One of the most significant changes is the inclusion of multiple choice and short answer type questions. The aim of these questions is to enhance student understanding and give lecturers the chance to see the type of questions that they might set for students to test their understanding of the material covered in the book. Solutions to the multiple choice are included and lecturers may obtain answers to the short answer questions at the website.

One final point about this book is that the fast changes in the world of finance make it hard for any author to keep abreast of all developments. To this end, the present book is not heavy on institutional detail, preferring to concentrate on the key theories and underlying principles. A thorough understanding of these should enable the reader to understand and interpret developments for themselves. 


\section{Acknowledgements}

In writing this book, I have been extremely fortunate to have had valuable discussions and receive comments on various draft chapters from numerous people. This second edition builds upon the first edition and I should like to thank Professor John Cubbin, Professor David Mayes, Professor David Greenaway, Professor Ali El-Agraa, Dr Alan Webber, Dr Johannes Fedderke, Dr Everton Dockery, Dr Dimtrios Asteriou, Dr Andy Denis, Dr Andy Adams and Dr Jason Laws for comments and suggestions on one, or in some cases, both editions. At the same time, I should make clear that any errors or shortcomings are entirely those of the author! In addition, many thanks are due to students at City University, Cass Business School and Boston University as well as participants in various Executive and Banking courses held at the Executive Development Centre. They were subjected to the contents of the book and have had a significant impact upon the final product. I should like to thank The Financial Times for allowing me to use its tables of financial data and the Financial Analysts Journal for permission to adapt materials for Figure 7.6. Finally, I should like to thank commissioning people at Palgrave Macmillan, Stephen Rutt, Stephen Wenham and Anna Faherty for their enthusiastic and excellent support throughout the duration of the project, and Keith Povey for his usual excellent assistance at the production phase.

Keith Pilbeam

Every effort has been made to trace all the copyright-holders, but if any have been inadvertently overlooked the publishers will be pleased to make the necessary arrangement at the first opportunity. 